\title{
Rumen degradation and fractional outflow rates of nitrogen supplements given to cattle eating sodium hydroxide-treated straw
}

\author{
BY K. AMANING-KWARTENG, R. C. KELLAWAY* \\ AND JANE LEIBHOLZ \\ Department of Animal Husbandry, University of Sydney, Camden, \\ New South Wales 2570, Australia \\ AND A. C. KIRBY \\ Department of Genetics and Biometry, University of Sydney, \\ New South Wales 2006, Australia
}

(Received 9 November 1984 - Accepted 21 October 1985)

\begin{abstract}
1. Six rumen and abomasal cannulated heifers were used to study the effects of intake on the fractional outflow rates (FOR) of chromium-mordanted cotton-seed meal (Cr-CSM) and meat meal (Cr-MM), CrEDTA, ytterbium and lignin from the rumen. Values of FOR of Cr-CSM and Cr-MM were combined with values of nitrogen disappearance from the protein supplements, placed in porous synthetic (nylon) bags and incubated within the rumen $(P)$, to calculate effective degradation $(D)$ of CSM and MM when fed to heifers eating sodium hydroxide-treated straw. Also, $\mathrm{N}$ degradation in vivo $(V)$ was measured as the difference between abomasal $\mathrm{N}$ flow and the sum of flows of microbial and endogenous $N$.

2. FOR were positively related to intake and differences between supplements were significant $(P<0 \cdot 01)$. FOR pertaining to high and low intakes respectively were 0.073 and 0.052 for $\mathrm{Cr}-\mathrm{CSM}, 0.082$ and 0.071 for $\mathrm{Cr}-\mathrm{MM}$, 0.030 and 0.023 for lignin, 0.082 and 0.073 for CrEDTA and 0.044 and 0.035 for $\mathrm{Yb}$.

3. A rise of 28.8 and $13.4 \%$ in FOR of Cr-CSM and Cr-MM respectively, associated with an increase in intake from maintenance to 1.5 times maintenance, resulted in 10.7 and $2.2 \%$ reductions in $D, 24 \mathrm{~h}$ after feeding, for CSM and MM respectively.

4. With the exception of CSM at the high intake, estimates of $V$ were underestimated by $D$ and were $8 \cdot 6-25 \cdot 0 \%$ greater than the $D$ values when time of incubation $(t)=\infty$. The two techniques, however, ranked the degradation of the two supplements in the same order at both levels of intake.

5. Underestimation of $V$ by $D$ may be attributable to underestimation of $P$, overestimation of FOR (both resulting in underestimation of $D$ ) or overestimation of $V$ due to biases associated with the estimation of this part of the comparison. The relative importance of these factors remains to be determined.
\end{abstract}

Recent recommendations on protein requirements for ruminants, e.g. Agricultural Research Council (1980), are based on the concepts of rumen-degradable protein (RDP) to satisfy the requirements of microflora, and undegradable dietary protein (UDP) plus microbial protein to meet the requirements of the animal. In order to apply such recommendations, the RDP and UDP contents of dietary proteins have to be known. The nylon-bag technique has been used to estimate rates of rumen degradation of proteins (Mehrez \& Ørskov, 1977). However, the effective degradation $(D)$ of proteins is determined by their retention time in the rumen as well as their rate of degradation in the rumen (Ørskov et al. 1980). Ganev et al. (1979) observed that increasing the intakes of a basal diet leads to increased fractional outflow rate (FOR) of protein supplements which would result in underestimation of the effective degradation of supplements given with the basal diet. This was confirmed by Sriskandarajah et al. (1981). Most of the studies in this area have involved soya-bean and fish meals (Mansbridge \& Ørskov, 1980; Eliman \& Ørskov, 1984), with a few observations on cotton-seed meal (CSM) and rape-seed meal (Lindberg, 1982) and casein (Sriskandarajah 
et al. 1981). There do not appear to have been any quantitative measurements made on meat meal (MM). The basal diets in most of these studies have been hay or straw. In the present study, values of nitrogen disappearance from CSM and MM placed in porous synthetic (nylon) bags and incubated within the rumen $(P)$, were combined with estimates of FOR from the rumen of the protein supplements to calculate $D$. These estimates of $D$ were compared with in vivo measurements of protein degradation in the rumen $(V)$.

Alkali-treated straw was selected for use in the present study because of its very low content of protein, high edibility and reasonably high energy content. With these attributes, there was a minimal source of bias attributable to $\mathrm{N}$ flow at the abomasum from dietary sources other than the test protein. A preliminary report of some of this work was reported by Amaning-Kwarteng et al. (1984).

\section{MATERIALS AND METHODS \\ Nylon-bag measurements}

The relation between percentage $\mathrm{N}$ disappearance $(P)$ and time of incubation $(t)$ is exponential and can be described by the equation:

$$
P=a+b\left(1-\mathrm{e}^{-c t}\right)
$$

(Ørskov \& McDonald, 1979). The constants $a, b$ and $c$ are measures of the rapidly-soluble $\mathrm{N}$ fraction, the degradable $\mathrm{N}$ fraction and the rate constant for the degradation of $b$ respectively, and are particular to each protein and basal diet. To obtain the values to estimate these constants, CSM and MM, ground through a $2.5 \mathrm{~mm}$ screen, were incubated in nylon bags $(80 \times 170 \mathrm{~mm}, 25 \mu \mathrm{m}$ pore size) within the rumen of three heifers $(\mathrm{B}, \mathrm{D}$ and F) fitted with large rumen cannulas $(100 \mathrm{~mm}$ diameter $)$. The animals were given a basal diet of alkali-treated straw (see below) at 0.9 times ad lib. intake plus $500 \mathrm{~g}$ of a mixed supplement containing (by weight) 50 parts CSM and 50 parts MM. Air-dried CSM or MM $(5 \mathrm{~g})$ were incubated in a bag. Sets of three bags of both supplements were incubated concurrently in the rumen of each of the three heifers. The bags were withdrawn after 0 , $3,6,9,12,24,36$ or $48 \mathrm{~h}$ of incubation. After rinsing lightly under running tap-water for $3 \mathrm{~min}$ the bags were dried in a forced-draught oven for $8 \mathrm{~h}$ at $60^{\circ}$, followed by $12 \mathrm{~h}$ at $100^{\circ}$. Dry matter (DM) and $\mathrm{N}$ (by a microKjeldahl technique) were determined on the residues. Degradability of $\mathrm{N}$ was estimated by the percentage disappearance of $\mathrm{N}$ in the supplement from the bags. The constants $a, b$ and $c$ were calculated by an iterative least-squares procedure. The nylon-bag measurements were made immediately before the in vivo measurements.

\section{In vivo measurements}

Animals. Six Friesian heifers (A, B, C, D, E and F), aged 30 months, weighing about $290 \mathrm{~kg}$ live weight and fitted with large rumen cannulas $(100 \mathrm{~mm}$ diameter $)$ and simple abomasal cannulas were housed in individual pens. Heifers ( B, D and F) were the same animals used in the nylon-bag measurements.

Diets and feeding regimen. Straw from a crop of semi-winter wheat, Triticum aestivum (cv. Shortim), was hammer-milled $(30 \mathrm{~mm}$ screen) and sprayed with sodium hydroxide solution $(44 \mathrm{~g} \mathrm{NaOH}$ in $113 \mathrm{~g}$ water $/ \mathrm{kg}$ ) followed by a mineral solution supplying $(\mathrm{g} / \mathrm{kg})$ : 79 water, $14 \mathrm{~N}, 1$ sulphur and 1.5 phosphorus and $(\mathrm{mg} / \mathrm{kg}): 4$ copper, 0.1 cobalt and sprinked with limestone supplying $2 \mathrm{~g}$ calcium $/ \mathrm{kg}$. Straw was treated in $250-\mathrm{kg}$ batches in a trailer mixer fitted with spray nozzles, and was stored in hessian bags for at least $7 \mathrm{~d}$ before feeding. Treated straw was given in buckets, automatically, at 3-h intervals at high $(0.9$ times ad lib.) and low ( 0.6 times high) levels of intake. These intakes were equivalent to 1.5 times 
maintenance and maintenance requirements respectively. The ad lib. level of intake was determined during a preliminary period of $14 \mathrm{~d}$ when animals were offered $20 \%$ in excess of their intake of the previous day. The heifers received once daily, a $500 \mathrm{~g}$ supplement of either CSM or MM. The four dietary treatments tested were: high intake, CSM; high intake, MM; low intake, CSM ; low intake, MM. Each of the four diets was offered to each heifer in an incomplete Latin-square design over four periods, so that there was a total of six observations per treatment mean. During each period, measurements of digesta markers and abomasal flows were made after $14 \mathrm{~d}$ of preliminary feeding. This was followed by measurements of outflow rates of Cr-CSM and Cr-MM.

Digesta markers and abomasal flow measurements. The quantity and composition of true digesta flowing from the abomasum and rumen outflow rates of liquid and particulate matter were determined by reference to CrEDTA as the liquid-phase marker, and ytterbium as the particulate marker. CrEDTA was prepared as described by Binnerts et al. (1968) and sprayed on alkali-treated straw to supply $200 \mu \mathrm{g} \mathrm{Cr} / \mathrm{kg}$. Yb marker was prepared by dissolving ytterbium nitrate in water and sprayed to supply $150 \mathrm{mg} \mathrm{Yb} / \mathrm{kg}$ straw. The marked straw was fed to the six heifers for $13 \mathrm{~d}$ after the preliminary period. During the last $3 \mathrm{~d}$, twelve samples each of rumen and abomasal digesta were collected at intervals distributed throughout the $24 \mathrm{~h}$ cycle. Bulked rumen and abomasal samples were stored at $-10^{\circ}$. At the end of the period the feeding of marked straw was terminated and rumen contents sampled six times within the following $32 \mathrm{~h}$.

Outflow rates of $C r$-CSM and $C r-M M$. Quantitative observations were made of the effect of intake on FOR of Cr-mordanted CSM (Cr-CSM) and MM (Cr-MM) from the rumen of heifers eating $\mathrm{NaOH}$-treated straw. $\mathrm{Cr}$ was complexed with $\mathrm{CSM}$ and $\mathrm{MM}$ according to Udén et al. (1980). Sodium chromate was applied at $139 \mathrm{~g} / \mathrm{kg}$ DM of protein supplement. The $\mathrm{Cr}$ complex, after reduction with ascorbic acid, was thoroughly washed until free of soluble green matter and dried at $65^{\circ}$. The Cr-CSM and Cr-MM were used to determine outflow rates of the untreated supplements from the rumen. During this measurement, which lasted $13 \mathrm{~d}$, heifers were given unmarked alkali-treated straw. On day 10 during this measurement, heifers were given a single meal (22-36 g) of either $\mathrm{Cr}-\mathrm{CSM}$ or $\mathrm{Cr}-\mathrm{MM}$ which was thoroughly mixed with the day's protein supplement. This was generally consumed within $5 \mathrm{~min}$. The entire rumen contents were emptied manually at $2,5,8,11$ and $26 \mathrm{~h}$ after administering the $\mathrm{Cr}$-mordant: they were then weighed, mixed and subsampled. Samples were analysed for DM, Cr and lignin (Goering \& Van Soest, 1970). The rate of $\mathrm{Cr}$ dilution was used to estimate FOR of Cr-CSM and Cr-MM. Lignin turnover rate was estimated from the ratio, daily lignin intake: lignin concentration in the rumen.

Before feeding Cr-CSM and Cr-MM to heifers, DM recovery of both $\mathrm{Cr}$-mordants was compared with those of the corresponding untreated supplements. Air-dried samples $(5 \mathrm{~g})$ were incubated in nylon bags in the rumen of animals B, D and F for 3 and $50 \mathrm{~h}$ (three bags/sample per animal).

\section{Effective $N$ degradability}

The constants $a, b$ and $c$ from the nylon-bag measurements were combined with those of in vivo measurements of FOR to calculate $D$ of CSM and MM from the equation of Ørskov \& McDonald (1979):

$$
D=a+[b c /(c+k)]\left(1-\mathrm{e}^{-(c+k) t}\right),
$$

$D$ was calculated for each of the rate-constants and $k$ was appropriate to the outfl ow rates of CSM and MM when the basal diet was given at high and low levels of intake. The constants $a, b$ and $c$ obtained from the nylon-bag measurements were used in the prediction of $D$ at both high and low levels of intake (Ørskov \& McDonald, 1979; Ørskov et al. 1981). 


\section{Chemical analyses and calculations}

For estimation of bacterial protein in abomasal digesta, rumen bacteria were isolated from the rumen fluid samples according to Hutton $e t$ al. (1971). The $\mathrm{N}$ and 2, 6-diaminopimelic acid (DAPA) contents of dried bacteria and total digesta were determined and the respective $\mathrm{N}$ :DAPA for each sample calculated. The proportion of bacterial $\mathrm{N}$ in digesta was determined as the DAPA: $N$ of whole digesta divided by the DAPA: $N$ of the bacterial fraction.

Rumen fluid was filtered through nylon gauze to remove coarse particles. Abomasal samples were centrifuged at $2400 \mathrm{~g}$ for $20 \mathrm{~min}$ to obtain liquid-rich fractions. Feed, rumen, total abomasal samples and corresponding liquid-rich fractions were analysed for DM by drying in a forced-draught oven to constant weight at $50^{\circ}$. $\mathrm{N}$ was analysed by a microKjeldahl technique. DAPA in whole digesta and bacterial fractions was determined using ion-exchange chromatography (TSM Amino Acid AutoAnalyzer; Technicon Equipment Ltd, Sydney). $\mathrm{Cr}$ and $\mathrm{Yb}$ concentrations in rumen and abomasal samples were measured by atomic absorption spectrophotometry after being subjected to wet digestion (Sriskandarajah \& Kellaway, 1984). FOR of liquid and and particulate matter were determined with reference to $\mathrm{Cr}$ and $\mathrm{Yb}$ dilutions respectively.

True digesta were mathematically reconstituted from $\mathrm{Cr}$ and $\mathrm{Yb}$ concentrations in total digesta and in liquid-rich fractions. The flow of digesta from the abomasum was corrected to $100 \%$ recovery of the daily dose of $\mathrm{Cr}$ input and calculated by using eqns (1)-(3) from Faichney (1975).

Estimates of $V$ were calculated as total abomasal $\mathrm{N}$ flow minus the sum of bacterial, endogenous and straw $\mathrm{N}$ flows. Endogenous $\mathrm{N}$ was calculated as $4 \mathrm{~g} / \mathrm{kg}$ DM intake (DMI) (Hart et al. 1982), and straw N flow as $1.73 \mathrm{~g} / \mathrm{kg}$ DMI (J. Spragg and R. C. Kellaway, unpublished results).

\section{Statistical analyses}

Variations in the constants of the equation $P=a+b\left(1-\mathrm{e}^{-c t}\right)$ pertaining to nylon-bag measurements were analysed as a randomized complete block design with subsamples. The effect of the supplement was tested against residual mean square ( $2 \mathrm{df})$. Both the coefficients of variation based on the variation between bags within a treatment and a heifer and that based on experimental error are presented. They were calculated from subsampling and residual mean squares respectively as $\sqrt{ }($ EMS $) / \bar{X}$, where $\bar{X}$ is the grand mean and EMS is the experimental error mean square (Steel \& Torrie, 1980).

The values pertaining to rumen characteristics and digesta kinetics were examined by analysis of variance for an incomplete Latin-square design. Effects of intake, supplement and intake $\times$ supplement interaction were tested against residual mean square (12 df ). The least significant difference $(P<0.05)$ was used to compare treatment means (Steel \& Torrie, 1980).

\section{RESULTS}

\section{Nylon-bag measurements}

Table 1 shows the coefficients describing digestion kinetics of $\mathrm{N}$ in nylon bags. $\mathrm{MM}$ had a larger soluble fraction $(P<0.01)$, a smaller degradable fraction $(P<0.05)$ and a higher rate of degradation than CSM. The $45 \%$ difference in fractional degradation constant was of biological significance although not statistically significant $(P>0.05)$. The coefficients of variation based on EMS were very large, especially that of $c$.

Mean values of DM recovery and standard deviations are presented in Table $2 . \mathrm{Cr}$ treatment reduced percentage DM loss of CSM in bags from 29 to 1.0 after $3 \mathrm{~h}$ and from $64 \cdot 1$ to 5.4 after $50 \mathrm{~h}$ of incubation. The corresponding reduction in MM DM loss due to $\mathrm{Cr}$ treatment was from 31.3 to $3.2 \%$ after $3 \mathrm{~h}$ and from 41.9 to $7.1 \%$ after $50 \mathrm{~h}$ of incubation. 
Table 1. Constants in equation $\overline{\mathrm{P}}=\mathrm{a}+\mathrm{b}\left(l+e^{-\mathrm{ct}}\right)$, where $\overline{\mathrm{P}}$ is percentage nitrogen disappearance after time-periods ( $\mathrm{t}$, hours) of incubation, from cotton-seed meal (CSM) and meat meal $(M M)$ incubated in nylon bags within the rumen of heifers given sodium hydroxidetreated straw (at 0.9 times ad lib. intake) plus $500 \mathrm{~g}$ mixed supplements $\dagger$

(Values are means of three heifers $\times$ three bags $/$ heifer; $n$ 9)

\begin{tabular}{|c|c|c|c|c|}
\hline Coefficients.. & $\begin{array}{c}a \\
\text { Soluble }\end{array}$ & $\begin{array}{c}b \\
\text { Degradable }\end{array}$ & $\begin{array}{c}c \\
\text { Fractional } \\
\text { degradation }\end{array}$ & $\begin{array}{c}100-(a+b) \\
\text { Undegradable }\end{array}$ \\
\hline \multicolumn{5}{|l|}{ Supplement $\ddagger$} \\
\hline CSM & $7 \cdot 26$ & $65 \cdot 33$ & 0.066 & $27 \cdot 41$ \\
\hline MM & $29 \cdot 65$ & 33.76 & $0 \cdot 120$ & 36.59 \\
\hline Standard error of difference ( $2 \mathrm{df}) \S$ & 0.965 & $6 \cdot 207$ & 0.0209 & 5.748 \\
\hline Statistical significance & $* *$ & $\bullet$ & NS & NS \\
\hline \multicolumn{5}{|l|}{ Coefficient of variation $(\%) \S$ based on: } \\
\hline Variations between bags & 1.820 & 1.079 & 6.7787 & $2 \cdot 284$ \\
\hline Experimental error & 11.096 & $26 \cdot 576$ & $47 \cdot 7885$ & $38 \cdot 107$ \\
\hline
\end{tabular}

NS, not significant.

$* P<0.05, * *<0.01$.

$\uparrow 50$ parts by weight CSM and 50 parts by weight MM.

$\ddagger$ Both supplements were incubated at the same time within the rumen of the same animals.

$\S$ See statistical analysis, p. 390.

Table 2. Percentage dry matter recovery of untreated $(U)$ and chromium-treated $(T)$ cotton-seed meal (CSM) and meat meal (MM) incubated in nylon bags within the rumen of heifers given sodium hydroxide-treated straw (at 0.9 times ad lib. intake) plus $500 \mathrm{~g}$ mixed supplement*

(Values are means and standard deviations $\nmid$ for three heifers $\times$ three bags/heifer; $n$ 9)

\begin{tabular}{|c|c|c|c|c|c|c|c|c|}
\hline \multirow{3}{*}{$\begin{array}{l}\text { Period of } \\
\text { incubation } \\
\text { (h) }\end{array}$} & \multicolumn{4}{|c|}{ CSM } & \multicolumn{4}{|c|}{$\mathbf{M M}$} \\
\hline & \multicolumn{2}{|c|}{$\mathbf{U}$} & \multicolumn{2}{|c|}{$\mathrm{T}$} & \multicolumn{2}{|c|}{$\mathrm{U}$} & \multicolumn{2}{|c|}{$\mathrm{T}$} \\
\hline & Mean & SD & Mean & SD & Mean & SD & Mean & SD \\
\hline 3 & $71 \cdot 1$ & $2 \cdot 19$ & 98.9 & 1.66 & $68 \cdot 7$ & $3 \cdot 17$ & 96.8 & 1.76 \\
\hline 50 & 35.9 & 2.93 & 94.6 & $2 \cdot 27$ & $58 \cdot 1$ & $4 \cdot 57$ & 92.8 & 2.05 \\
\hline
\end{tabular}

* 50 parts by weight CSM + 50 parts by weight $\mathrm{MM}$.

$\dagger \mathrm{SD}(2 \mathrm{df})$ calculated for three heifers per treatment mean using average values of three bags per heifer.

In vivo measurements

Mean values of DM intake, rumen contents and FOR are given in Table 3. Outflow rates of CrEDTA, Yb, lignin, Cr-CSM and Cr-MM were higher at the high feed intake than at the low feed intake $(P<0.01)$. FOR of Cr-CSM was significantly less than that of Cr-MM.

Tables 4 and 5 respectively show the estimates of $D$ for CSM and MM calculated relative to measured $P$ and FOR values. Compared with the measured $P$ values, the fitted $(\bar{P})$ estimates do not appear to fit well at the beginning of the time-scale. There was only a slight and insignificant increase in $D(2.9-4.9 \%$ in CSM and $0.32-0.43 \%$ in MM) between $24 \mathrm{~h}$ and the final value when $D=a+b c /(c+k)$. A rise in $k(28.8 \%$ for CSM and $13.4 \%$ for 
Table 3. Dry matter (DM) intake (DMI), rumen contents and fractional outflow rates (FOR) from the rumen of heifers given a basal diet of sodium hydroxide-treated straw at two levels of intake plus a $500 \mathrm{~g}$ supplement $(S)$ of either cotton-seed meal (CSM) or meat meal (MM)

(Values are means of six heifers per treatment)

\begin{tabular}{|c|c|c|c|c|c|c|c|c|}
\hline \multirow{2}{*}{$\begin{array}{c}\text { S... } \\
\text { Intake... }\end{array}$} & \multicolumn{2}{|c|}{ CSM } & \multicolumn{2}{|c|}{$\mathbf{M M}$} & \multirow{2}{*}{$\begin{array}{l}\text { Standard } \\
\text { error of } \\
\text { difference } \dagger \\
(12 \mathrm{df})\end{array}$} & \multicolumn{3}{|c|}{$\begin{array}{c}\text { Statistical } \\
\text { significance }\end{array}$} \\
\hline & High & Low & High & Low & & I & $\mathrm{S}$ & $\mathrm{I} \times \mathrm{S}$ \\
\hline Total DMI (kg/d) & $7 \cdot 15$ & $4 \cdot 46$ & $7 \cdot 18$ & $4 \cdot 50$ & $0 \cdot 017$ & $* *$ & NS & NS \\
\hline Total rumen DM $(\mathrm{kg})$ & $6 \cdot 39$ & $4 \cdot 77$ & $6 \cdot 06$ & $4 \cdot 82$ & $0 \cdot 185$ & $* *$ & NS & NS \\
\hline Total rumen fluid (l) & 48.6 & $46 \cdot 5$ & $48 \cdot 8$ & $41 \cdot 6$ & $2 \cdot 45$ & NS & NS & NS \\
\hline \multicolumn{9}{|l|}{ Outflow rates $(/ \mathrm{h})$} \\
\hline Chromium supplement & 0.073 & 0.052 & 0.082 & 0.071 & 0.0016 & $* *$ & $* *$ & ** \\
\hline Lignin & 0.029 & 0.022 & 0.030 & 0.023 & 0.0010 & $* *$ & NS & NS \\
\hline CrEDTA & 0.081 & 0.072 & $0 \cdot 082$ & 0.074 & $0 \cdot 0022$ & $* *$ & NS & NS \\
\hline Ytterbium & 0.044 & 0.034 & $0 \cdot 044$ & 0.036 & 0.0020 & $* *$ & NS & NS \\
\hline
\end{tabular}

High, 0.9 times ad lib. intake; low, 0.6 times high intake; NS, not significant.

** $P<0.01$

$\uparrow$ Interaction means.

Table 4. Effective nitrogen degradability (D) of cotton-seed meal calculated from percentage $N$ disappearance from nylon bags at different time-periods $(\mathrm{t})$ of incubation and in vivo fractional outflow rate measurements

\begin{tabular}{|c|c|c|c|c|c|}
\hline \multirow{3}{*}{$\begin{array}{l}\text { Period after } \\
\text { incubating } \\
\text { a supplement } \\
\text { ( } t \text {, hours) }\end{array}$} & \multirow{3}{*}{$\begin{array}{l}\text { Fractional } \\
\text { outflow } \\
\text { rate }(/ h) \ldots\end{array}$} & \multicolumn{2}{|c|}{$\begin{array}{c}\text { Percentage disappearance of } \\
\mathrm{N} \text { from nylon bags } \\
\text { after time } t\end{array}$} & \multicolumn{2}{|c|}{$\begin{array}{l}\text { Calculated effective } \\
\mathrm{N} \text { degradation after } \\
\text { time } t(D)\end{array}$} \\
\hline & & $\begin{array}{l}\text { Experimentally } \\
\text { determined } \\
\qquad(P)\end{array}$ & $\begin{array}{l}\text { Fitted } \\
(\bar{P})\end{array}$ & High intake & Low intake \\
\hline & & 0 & 0 & 0.073 & 0.052 \\
\hline 3 & & 23.84 & $18 \cdot 99$ & $17 \cdot 84$ & $18 \cdot 15$ \\
\hline 6 & & $28 \cdot 74$ & $28 \cdot 62$ & $24 \cdot 81$ & $25 \cdot 80$ \\
\hline 9 & & 35.63 & $36 \cdot 52$ & $29 \cdot 40$ & $31 \cdot 17$ \\
\hline 12 & & $42 \cdot 17$ & 43.00 & $32 \cdot 43$ & 34.93 \\
\hline 24 & & $53 \cdot 54$ & $59 \cdot 19$ & $37 \cdot 18$ & $41 \cdot 65$ \\
\hline- & & - & $72 \cdot 59$ & $38 \cdot 28$ & 43.80 \\
\hline
\end{tabular}

$P$, values were means of three heifers $\times$ three bags per heifer; $\bar{P}=a+b l-\mathrm{e}^{-c t}$ ), using constants in Table 1. The equation was constrained such that $a+b$ did not exceed 100 and $100-(a+b)$ was the undergradable fraction;

$$
D=a+[b c /(c+k)]\left(1-\mathrm{e}^{-(c+k) t}\right)
$$

assuming $\varnothing$ rskov \& McDonald (1979) is appropriate. The constants from the nylon-bag measurements were used in the calculation of $D$ for both high ( 0.9 times $a d$ lib. intake) and low ( 0.6 times high intake) levels of intake (for details, see p. 389). 
Table 5. Effective nitrogen degradation (D) of meat meal calculated from percentage $N$ disappearance from bags at different time-periods $(\mathrm{t})$ of incubation and in vivo fractional outflow measurements

\begin{tabular}{|c|c|c|c|c|c|}
\hline \multirow{3}{*}{$\begin{array}{l}\text { Period after } \\
\text { incubating } \\
\text { a supplement } \\
(t, \text { hours })\end{array}$} & \multirow{3}{*}{$\begin{array}{c}\text { Fractional } \\
\text { outflow } \\
\text { rate }(/ \mathrm{h}) \ldots\end{array}$} & \multicolumn{2}{|c|}{$\begin{array}{l}\text { Percentage disappearance of } \\
\mathrm{N} \text { from nylon bags } \\
\text { after time } t\end{array}$} & \multicolumn{2}{|c|}{$\begin{array}{l}\text { Calculated effective } \\
\mathrm{N} \text { degradation after } \\
\text { time } t(D)\end{array}$} \\
\hline & & $\begin{array}{l}\text { Experimentally } \\
\text { determined } \\
(P)\end{array}$ & $\begin{array}{l}\text { Fitted } \\
\qquad(\bar{P})\end{array}$ & High intake & Low intake \\
\hline & & 0 & 0 & 0.082 & 0.071 \\
\hline 3 & & 44.58 & 39.86 & $38 \cdot 76$ & 38.90 \\
\hline 6 & & 48.83 & 46.98 & $43 \cdot 74$ & $44 \cdot 12$ \\
\hline 9 & & 50.74 & 51.95 & $46 \cdot 45$ & 47.06 \\
\hline 12 & & 52.20 & 55.41 & 47.93 & 48.72 \\
\hline 24 & & $57 \cdot 11$ & $61 \cdot 51$ & $49 \cdot 55$ & $50 \cdot 64$ \\
\hline- & & - & $63 \cdot 41$ & $49 \cdot 71$ & 50.86 \\
\hline
\end{tabular}

$P$, values were means of three heifers $\times$ three bags per heifer; $\bar{P}=a+b\left(1-\mathrm{e}^{-c t}\right)$, using constants in Table 1 . The equation was constrained such that $a+b$ would not exceed 100 and $100-(a+b)$ was the undergradable fraction;

$$
D=a+[b c /(c+k)]\left(1-\mathrm{e}^{-c+k) t}\right),
$$

assuming Ørskov \& McDonald (1979) is appropriate. The constants from the nylon-bag measurements were used in the calculation of $D$ for both high ( 0.9 times $a d$ lib. intake) and low ( 0.6 times high intake) levels of intake (for details, see p. 389).

MM) due to an increase in intake from maintenance to 1.5 times maintenance resulted in reductions of 10.7 and $2.2 \%$ in $D$ (24 h after feeding a supplement) for CSM and MM respectively.

Estimates of protein degradation calculated from abomasal digesta flow (Table 6) show that $\mathrm{MM}$ was $32 \%$ more degraded than CSM and that degradation was significantly higher $(P<0.01)$ at the low level of intake than at the high level of intake. Mean differences between MM and CSM were 20.2 and 19.1 at low and high intakes respectively with this interaction between supplements and intake being non-significant $(P>0 \cdot 05)$.

\section{Comparison of calculated $\mathrm{D}$ and estimated $\mathrm{V}$ values}

A summary of the estimated $V$ values compared with the calculated $D$ values is shown in Table 7. With the exception of CSM at the high level of intake, calculated $D$ values underestimated the $V$ values. There was a strong heterogeneity of variance for the data obtained by the two methods compared and, for this reason, statistical comparison was not possible. The two methods, however, ranked the degradability of the supplements in the same order at both levels of intake.

\section{DISCUSSION}

The generally high coefficient of variation based on EMS was due, at least in part, to the small number of animals used. The excessively large coefficient of variation of $c$ makes the statistical comparison of the two treatments for this index unreliable. The position of the bags in the rumen could be responsible for the relatively high between-bag variation in $c$. In this experiment, a weight of $45 \mathrm{~g}$ was attached to the bags in order to anchor them 
Table 6. Calculations of in vivo degradation of cotton-seed meal (CSM) and meat meal (MM) from digesta flow at the abomasum of heifers given a basal diet of sodium hydroxide-treated straw at two levels of intake plus $500 \mathrm{~g} C S M$ or $M M / d$

(Values are means of six heifers per treatment)

\begin{tabular}{|c|c|c|c|c|c|c|c|}
\hline \multirow{2}{*}{$\begin{array}{l}\text { Supplements }(\mathrm{S}) \ldots \\
\text { Intake }(\mathrm{I}) \ldots\end{array}$} & \multicolumn{2}{|c|}{ CSM } & \multicolumn{2}{|c|}{ MM } & \multirow{2}{*}{$\begin{array}{c}\text { SED } \\
(12 \mathrm{df})\end{array}$} & \multicolumn{2}{|c|}{$\begin{array}{c}\text { Statistical } \\
\text { significance } \dagger\end{array}$} \\
\hline & High & Low & High & Low & & I & $\mathbf{S}$ \\
\hline \multicolumn{8}{|l|}{ Abomasal nitrogen flow $(\mathrm{g} / \mathrm{d})$} \\
\hline Total & $136 \cdot 8$ & $89 \cdot 7$ & $137 \cdot 0$ & $91 \cdot 8$ & $3 \cdot 38$ & $* *$ & NS \\
\hline Bacterial & $78 \cdot 0$ & $49 \cdot 0$ & $80 \cdot 0$ & $55 \cdot 1$ & $3 \cdot 14$ & $* *$ & NS \\
\hline Endogenous & $27 \cdot 3$ & $17 \cdot 4$ & $27 \cdot 6$ & $17 \cdot 2$ & $1 \cdot 71$ & $* *$ & NS \\
\hline Straw§ & $11 \cdot 0$ & 6.7 & $11 \cdot 1$ & $6 \cdot 6$ & $0 \cdot 18$ & $* *$ & NS \\
\hline \multicolumn{8}{|l|}{ Supplemental N (g/d) } \\
\hline Intake & $31 \cdot 7$ & $31 \cdot 7$ & $40 \cdot 1$ & $40 \cdot 1$ & & & \\
\hline Flow at abomasum $\|$ & $20 \cdot 5$ & $16 \cdot 6$ & $18 \cdot 3$ & 12.9 & $2 \cdot 50$ & NS & NS \\
\hline Degraded & $11 \cdot 3$ & $15 \cdot 1$ & $21 \cdot 8$ & $27 \cdot 2$ & $2 \cdot 04$ & $*$ & ** \\
\hline $\begin{array}{l}\text { Degraded as percentage } \\
\text { of intake ( } 24 \mathrm{~h} \\
\text { after intake) }\end{array}$ & $35 \cdot 3$ & $47 \cdot 6$ & $54 \cdot 4$ & $67 \cdot 8$ & 3.89 & $* *$ & ** \\
\hline
\end{tabular}

High, 0.9 times ad lib. intake; low, 0.6 times high intake; SED, standard error of difference for interaction means; NS, not significant.

$\dagger$ I $\times S$ interactions were not significant.

$\ddagger$ Calculated as $4 \mathrm{~g} / \mathrm{kg}$ dry matter intake (Hart et al. 1982 ).

$\S$ Calculated as $1.73 \mathrm{~g} / \mathrm{kg}$ dry matter intake (J. Spragg, unpublished results).

\| Total abomasal $\mathrm{N}$ flow -(bacterial + endogenous + straw) $\mathrm{N}$ flow.

Table 7. Comparison of estimated percentage in vivo nitrogen degradation (V) and calculated effective $N$ degradability (D) of cotton-seed meal (CSM) and meat meal (MM) given to heifers eating sodium hydroxide-treated straw at two levels of intake plus $500 \mathrm{~g} C S M$ or $M M / d$

(Values are means of six heifers (for $V$ values) or three heifers (for $D$ values) and their respective standard deviations)

\begin{tabular}{|c|c|c|c|c|c|c|}
\hline \multirow{2}{*}{$\begin{array}{l}\text { Level } \\
\text { of intake }\end{array}$} & \multirow[b]{2}{*}{ Supplement } & \multicolumn{2}{|c|}{$\begin{array}{l}\text { Estimated in vivo } \\
\mathbf{N} \text { degradation }\end{array}$} & \multicolumn{2}{|c|}{$\begin{array}{l}\text { Calculated effective } \\
\mathrm{N} \text { degradability }\end{array}$} & \multirow{2}{*}{$\frac{D \times 100}{V}$} \\
\hline & & $(V)^{*}$ & SD & $(D)^{\dagger}$ & SD & \\
\hline \multirow[t]{2}{*}{ High } & CSM & $35 \cdot 3$ & 1.65 & $38 \cdot 28$ & 0.58 & $108 \cdot 0$ \\
\hline & $\mathbf{M M}$ & $54 \cdot 4$ & $2 \cdot 01$ & $49 \cdot 71$ & 0.91 & $91 \cdot 4$ \\
\hline \multirow[t]{2}{*}{ Low } & $\mathrm{CSM}$ & $47 \cdot 6$ & $2 \cdot 28$ & 43.80 & 0.63 & $92 \cdot 0$ \\
\hline & $\mathbf{M M}$ & $64 \cdot 8$ & $2 \cdot 90$ & $50 \cdot 86$ & 0.65 & $75 \cdot 0$ \\
\hline
\end{tabular}

High, 0.9 times ad lib. intake; low 0.6 times high intake.

* From Table 6.

$\dagger$ From Tables 4 and 5 when period of incubation $(t)=\infty$

in the ventral sac where digestion is most rapid (Miles, 1951). Mehrez \& Ørskov (1977), however, found that this procedure had no effect in reducing variation between bags. Significant differences in N degradability between soya-bean meal (SBM) and CSM were observed by Hughes-Jones (1979). The constants $a, b$ and $c$ were $9 \cdot 5,77 \cdot 8$ and $0 \cdot 08$ for SBM and $29 \cdot 2,36.5$ and 0.063 for CSM respectively. Differences in coefficients for CSM observed 
by us and Hughes-Jones (1979) may be attributable to differences in the extent of heating during processing as well as differences in the basal diet; the coefficients are affected by the passage rate of the basal diet (Ganev et al. 1979). The effects of processing on $\mathrm{N}$ degradation have been substantiated by Chapman \& Norton (1982) and, more recently, by Freer \& Dove (1984). The former authors observed that fresh, frozen forage samples had significantly greater $c$ values than dried samples. Comparing the degradations of $\mathrm{N}$ from sunflower meals and rapeseed meals, the latter workers found that there was as much difference between two batches of sunflower meal as there was between either of them and rapeseed meal.

Increases in the rate of passage of Cr-treated supplements from the rumen with increase in intake have been reported by Ganev et al. (1979), Mansbridge \& Ørskov (1980) and Lindberg (1982) for Cr-CSM, Cr-fish meal (FM) and Cr-rapeseed meal (Cr-RSM). Our results provide a quantitative description of the effect.

The significant difference in FOR between Cr-CSM and Cr-MM suggests that values obtained with one protein supplement might not be applicable to others. Mansbridge \& Orskov (1980) observed small differences between Cr-FM and Cr-soya-bean meal (Cr-SBM) outflow rates. Also, Lindberg (1982) observed small differences between Cr-CSM, Cr-SBM and Cr-RSM outflow rates at both maintenance and 3 times maintenance levels of intake. Larger and significant differences observed in the present study may be due to the highly significant difference in the soluble fractions of the two supplements (Table 1). Differences in solubility would result in differences in the distribution of the two supplements between the rumen liquid and particulate phases.

The range of FOR of $\mathrm{Cr}$ supplements obtained in the present study is similar to that of Sriskandarajah et al. (1981) who studied $\mathrm{H}^{14} \mathrm{CHO}$-casein in wethers given $\mathrm{NaOH}$-treated straw $(0 \cdot 048-0.083 / \mathrm{h})$ and those of Eliman \& Orskov (1984) who used Cr-FM in dairy cows in early lactation and gave a mixed diet $(0.066-0.091 / \mathrm{h})$. Our values are, however, higher than those obtained by Lindberg (1982) who studied Cr-CSM, Cr-SBM and Cr-RSM in dry cows (0.034-0.062) and Eliman \& Ørskov (1984) when they used Cr-FM and Cr-SBM in sheep given long, dried grass $(0 \cdot 008-0.038)$. These results suggest that the basal diet has a major effect on FOR and show that a constant FOR of protein supplements from the rumen cannot be assumed in the calculation of $D$ in the rumen when different basal diets are given.

Reports relating level of intake to liquid and particulate FOR have not been consistent. No significant changes in liquid FOR were observed in sheep given three levels of intake of a hay-grain diet (Hodgson et al. 1976). Similarly, no increase in FOR of rumen solids was observed when the intake of the basal diet was increased (Waldo et al. 1965; McAllan \& Smith, 1976). Direct positive relations, such as those observed in the present study, have been reported by Minson (1966), Owens et al. (1979), Evans (1981 $a, b$ ) and Warner (1981). In a series of experiments, Grovum \& Williams $(1973,1977)$ observed an increased FOR from the rumen, small intestine, large intestine, caecum and colon with increased feeding level. This phenomenon is probably associated with voluntary water consumption as water intakes generally parallel DM intake.

FOR of CrEDTA observed in the present study was lower than that $0.093 / \mathrm{h}$ reported by Sriskandarajah \& Kellaway (1984) for cattle eating a similar diet of $\mathrm{NaOH}$-treated straw. Major differences in experimental procedure between the two studies are that steers were given $\mathrm{NaOH}$-treated straw ad lib. by Sriskandarajah \& Kellaway (1984) and received no supplemental energy, whereas the heifers in the present study were given a maximum of 0.9 times $a d$ lib. intake and also received supplements of either CSM or MM. Decreases in rumen fluid FOR with decreased DM intake were reported by Evans (1981 a). Decreased rumen fluid FOR with increased grain or energy content of the diet have also been reported in sheep (Grubb \& Dehority, 1975) and in cattle (Prange et al. 1979). It is possible that 
concentrate feeding may also cause reduced solid FOR. Such a phenomenon could be due to alterations in the microbial population.

Reduction in $D$ with increases in FOR of the supplement agrees with the observation of Ørskov et al. (1981) who calculated that $D$ of SBM would be reduced from $89.1 \%$ at FOR of $0.01 / \mathrm{h}$ to $67.7 \%$ at FOR of $0.04 / \mathrm{h}$. In the present study, $24 \mathrm{~h}$ after feeding supplements, $D$ of CSM decreased from 41.65 at FOR of $0.052 / \mathrm{h}$ to 37.18 at FOR of $0.073 / \mathrm{h}$. The corresponding decrease in $D$ of MM was from 50.64 at FOR of 0.071 to 49.55 at FOR of $0.082 / \mathrm{h}$. Our observed responses were smaller than those of Ørskov et al. (1981), probably due to the lower degradabilities of CSM and MM than that of SBM in the rumen. At $24 \mathrm{~h}$ after feeding, there was no difference between $P$ of CSM and MM. However, the corresponding values of $D$ were significantly different. Higher outflow rates caused lower degradability. In the present study the effect of higher FOR of MM was confounded by its substantially higher $c$ with the net result that MM was effectively more degraded than CSM. Mehrez \& Ørskov (1977) observed that both the extent of protein degradation and its rate of degradation should be considered when comparing the degradabilities of different protein sources. Ganev et al. (1979) concluded that while rumen outflow of potentiallydegradable material has importance, the rate of degradation has the greater effect. Values of $D, 24 \mathrm{~h}$ after feeding a supplement, were not different from the $D$ values predicted for $t=\infty$. This is of great practical value and supports the observation of Ørskov \& McDonald (1979) that $24 \mathrm{~h}$ is a sufficiently appropriate incubation time for protein supplements in nylon bags in the rumen when studying the percentage $\mathrm{N}$ disappearance from the bags. The use of the same constants $(a, b$ and $c$ ) in the calculation of $D$ at both high and low intakes (as by Ørskov \& McDonald, 1979; Ørskov et al. 1981) assumes that the level of feeding does not affect these estimates of nylon-bag measurements. There has not been any quantitative information, however, to substantiate this assumption. This is a relevant area which needs investigation.

The method for estimating $V$ also identified differences in the degradabilities of the two supplements and provided information about the rumen metabolism of the proteins. The application of this method is, however, limited because it is unsuitable for the assessment of large numbers of ingredients at a time. Also, the single degradation value obtained for each material is applicable only to the particular feeding situation. A change in feeding level will alter the $V$ values. The technique further suffers from the disadvantage that errors present in the determination of the microbial $\mathrm{N}$ is, by subtraction, transferred to the generally much smaller undegraded dietary $\mathrm{N}$. Estimates of microbial $\mathrm{N}$ have also varied considerably between different microbial markers used. For example, Punia \& Leibholz (1984) found microbial $\mathrm{N}$ based on ${ }^{35} \mathrm{~S}$ to be $21 \%$ higher than that based on DAPA. The usual explanation is that DAPA takes no account of the protozoal $\mathrm{N}$ contribution in the digesta. Sampling of the gut contents distal to the rumen to estimate total $\mathrm{N}$ flow at the abomasum, combined with errors in estimating endogenous $\mathrm{N}$ flow, are additional sources of variation. Any variation in digesta flow-rates from the abomasum would change $\mathrm{N}$ retention time and therefore estimates of $\mathrm{N}$ degradation. We minimized the effect of this source of variation by sampling at regular intervals throughout the $24 \mathrm{~h}$ cycle.

Attempts by earlier workers to make direct comparisons between nylon-bag degradability measurements and $V$ have yielded inconsistent results (Chapman \& Norton, 1982, 1984; Freer \& Dove, 1984). The disparity could be attributed to the fact that the $P$ values were not corrected for FOR of the supplemental protein from the rumen. Chapman $\&$ Norton (1984) used three techniques, namely nylon-bag, ${ }^{35} \mathrm{~S}$-microbial-labelling and ${ }^{15} \mathrm{~N}$-plantlabelling procedures, to compare $P$ and $V$ of pangola grass (Digitaria decumbens) and siratro (Macroptilium atropurpureum). Estimates of $V$ based on the two isotope-labelling techniques gave higher values than those with the nylon bags. The nylon-bag and the in vivo 
techniques also ranked the degradabilities of the two feeds differently. It is note-worthy that the $P$ values were not corrected for FOR. Similar results were obtained by Mathers $\&$ Miller (1981) when $P$ and $V$ of dietary protein in the rumen of sheep given diets containing chopped lucerne (Medicago sativa) and rolled barley were compared. $V$ values were determined using a ${ }^{35} \mathrm{~S}$-labelling procedure. When a $k$ value was assumed from the work of Ørskov \& McDonald (1979) and used to correct for FOR in their study, Mathers \& Miller (1981) observed a remarkable similarity between $D$ and $V$ values.

We compared $D$ with $V$ estimates observed from analysis of abomasal digesta (Zinn et al. 1981). The similarity between estimated $V$ and calculated $D$ in the order they ranked the degradability of the two supplements at both levels of intake suggests that the nylon-bag technique is a useful tool for comparing the degradability of proteins when the $P$ values are corrected for FOR.

Our results agree with the findings of Armstrong \& Brookes (1981), Rooke et al. (1983) and Rooke \& Armstrong (1983) who observed that the nylon-bag method ranked different supplemental proteins in the same order of degradabilities as did the observed in vivo methods even though the $D$ values underestimated the $V$ values. Underestimation of $V$ by $D$ may be attributable to the underestimation of $P$, overestimation of FOR (both resulting in underestimation of $D$ ) or overestimation of $V$ due to biases associated with the estimation of this part of the comparison. The relative importance of these factors, as well as the possibility that the model of Ørskov \& McDonald (1979) might not be a sufficiently good approximation of in vivo degradation, remains to be determined. The attraction of the nylon-bag method lies in the ability to follow sequentially the rate of protein degradation as well as study the nutritive value of feed residues after rumen incubation in order to estimate the qualitative contribution of undegradable protein to the abomasum.

The results of the present study suggest that a constant outflow rate of protein supplements cannot be assumed in the calculation of effective protein degradation in the rumen. The large differences in $\mathrm{N}$ degradation between CSM and MM (with both $V$ and $D$ ) confirm that there cannot be a single value for the degradability of $\mathrm{N}$ in different protein supplements (Rooke \& Armstrong, 1983).

The authors wish to thank the Australian Meat Research Committee for financial support. The technical assistance of Mr R. Butchers, Ms Helena Warren and Mrs Lynn Swan is deeply appreciated. K. A.-K. is a recipient of a Special Commonwealth African Assistantship Plan (SCAAP) award while on study leave from the University of Ghana, Legon, Ghana.

\section{REFERENCES}

Agricultural Research Council (1980). The Nutrient Requirements of Ruminant Livestock. Slough: Commonwealth Agricultural Bureaux.

Amaning-Kwarteng, K., Kellaway, R. C. \& Leibholz, J. (1984). Proceedings of the Nutrition Society of Australia 9, 152 Abstr.

Armstrong, D. G. \& Brookes, L. M. (1981). In Recent Advances in Animal Nutrition in Australia, pp. 24-39 [D. J. Farrell, editor]. Armidale: University of New England Publishing Unit.

Binnerts, W. T., Van't Klooster, A. Th. \& Frens, A. M. (1968). Veterinary Record 82, 470.

Chapman, P. G. \& Norton, B. W. (1982). Proceedings of the Australian Society of Animal Production 14, $580-583$.

Chapman, P. G. \& Norton, B. W. (1984). Proceedings of the Australian Society of Animal Production 15, $286-289$.

Eliman, M. E. \& Ørskov, E. R. (1984). Animal Production 38, 45-51.

Evans, E. (1981 a). Canadian Journal of Animal Science 61, 91-96.

Evans, E. (1981 b). Canadian Journal of Animal Science 61, 97-103.

Faichney, G. J. (1975). In Digestion and Metabolism in the Ruminant, pp. 277-291 [I. W. McDonald and

A. C. I. Warner, editors]. Armidale: University of New England Publishing Unit.

Freer, M. \& Dove, H. (1984). Animal Feed Science and Technology 11, 87-101.

Ganev, G., Orskov, E. R. \& Smart R. (1979). Journal of Agricultural Science, Cambridge 93, 651-656. 
Goering, H. K. \& Van Soest, P. J. (1970). Forage Fiber Analyses. Agriculture Handbook no. 379. Washington, DC: US Department of Agriculture.

Grovum, W. L. \& Williams, V. J. (1973). British Journal of Nutrition 30, 313-329.

Grovum, W. L. \& Williams, V. J. (1977). British Journal of Nutrition 38, 425-436.

Grubb, J. A. \& Dehority, B. A. (1975). Applied Microbiology 30, 404-412.

Hart, F. J., Leibholz, J. \& Hogan, J. P. (1982). Proceedings of the Australian Society of Animal Production 14, 602 Abstr.

Hodgson, J. C., Thomas, P. C. \& Wilson, A. G. (1976). Journal of Agricultural Science, Cambridge 87, 297-302.

Hughes-Jones, M. (1979). MSc. Thesis, University of Aberdeen; cited by Ørskov, E. R., Hovell, F. D. DeB., \& Mould, F. (1980). Tropical Animal Production 5, 195-213.

Hutton, K., Bailey, F. J. \& Annison, E. F. (1971). British Journal of Nutrition 25, 165-173.

Lindberg, J. E. (1982). Journal of Agricultural Science, Cambridge 98, 689-691.

McAllan, A. B. \& Smith, R. H. (1976). British Journal of Nutrition 36, 511-522.

Mansbridge, R. J. \& Orskov, E. R. (1980). Animal Production 30, 486-487.

Mathers, J. C. \& Miller, E. L. (1981). British Journal of Nutrition 45, 587-604.

Mehrez, A. Z. \& Ørskov, E. R. (1977). Journal of Agricultural Science, Cambridge 88, 645-650.

Miles, J. T. (1951). Journal of Dairy Science 34, 492 Abstr.

Minson, D. I. (1966). British Journal of Nutrition 20, 765-773.

Ørskov, E. R., Hovell, F. D. DeB, \& Mould, F. (1980). Tropical Animal Production 5, 195-213.

Ørskov, E. R., Hughes-Jones, M. \& McDonald, I. (1981). In Recent Advances in Animal Nutrition, pp. 85-98 [W. Haresign, editor]. London: Butterworths.

Ørskov, E. R., \& McDonald, I. (1979). Journal of Agricultural Science, Cambridge 92, 499-503.

Owens, F. N., Kazemi, M., Galyean, M. L., Mizwicki, K. L. \& Solaiman, S. G. (1979). Okalahoma Agricultural Experimental Station Report MP-104, 27-29.

Prange, R. W., Stern, M. D., Rode, L. M., Santos, K. A. S., Jorgensen, N. A. \& Satter, L. D. (1979). Journal of Animal Science 49, 398 Abstr.

Punia, B. S. \& Leibholz, J. (1984). Canadian Journal of Animal Science 64, 24-25.

Rooke, J. A. \& Armstrong, D. G. (1983). In Proceedings of the Fourth International Symposium in Protein Metabolism and Nutrition, pp. 235-238 [R. Pian, M. Arnal and D. Bonin, editors]. Paris: INRA Publications. Rooke, J. A., Brookes, I. M. \& Armstrong, D. J. (1983). Journal of Agricultural Science, Cambridge 110, $329-342$. Sriskandarajah, N. \& Kellaway, R. C. (1984). British Journal of Nutrition 51, 289-296.

Sriskandarajah, N., Kellaway, R. C. \& Leibholz, J. (1981). Journal of Agricultural Science, Cambridge 97, 231-232. Steel, R. G. D. \& Torrie, J. H. (1980). Principles and Procedures of Statistics, 2nd ed. New York: McGraw-Hill. Udén, P., Colucci, P. E. \& Van Soest, P. J. (1980). Journal of the Science of Food and Agriculture 31, 625-632. Waldo, D. R., Miller, R. W., Okamoto, M. \& Moore, L. A. (1965). Journal of Dairy Science 48, 1473-1480.

Warner, A. C. I. (1981). Nutrition Abstracts and Reviews Series B 51, 789-820.

Zinn, R. A., Bull, L. S. \& Hemken, R. W. (1981). Journal of Animal Science 52, 857-866. 